\title{
Alencar e seu projeto literário de construção nacional
}

\author{
Eduardo Diatahy B. de Menezes
}

\section{Resumo}

Partindo da ideia de que o Brasil não dispõe de um poema épico, um romance nacional ou uma obra literária aceita como grande referência para a construção da nacionalidade, este ensaio enfatiza a deliberada missão intelectual que José de Alencar se atribuiu, de realizar o projeto literário da nação brasileira.

Palavras-chave: Literatura Brasileira; José de Alencar; Construção da Nacionalidade.

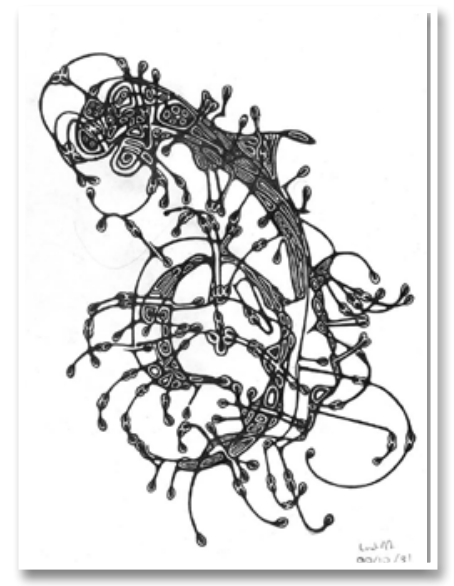

\section{Alencar and his literary project of nation building}

$\overline{\text { Eduardo Diatahy B. de Menezes }}$

Professor Emérito da Universidade Federal do Ceará (UFC), membro do Instituto do Ceará (Histórico, Geográfico e Antropológico), da Academia Cearense de Letras e da Academia Cearense de Ciências.

\begin{abstract}
Starting from the idea that Brazil does not have an epic poem, a national novel or a literary piece accepted as a great reference for the construction of nationality, this essay emphasizes the deliberate intellectual mission that José de Alencar attributed to himself to realize the literary project of the Brazilian nation.
\end{abstract}

Keywords: Brazilian Literature; José de Alencar; Construction of Nationality. 
Não consta que alguém já vivesse nesta abençoada terra do produto de obras literárias. E nosso atraso provém disso mesmo, e não daquilo que se vai desacreditando de antemão.

Quando as letras forem entre nós uma profissão, talentos que hoje apenas aí buscam passatempo ao espírito, convergirão para tão nobre esfera suas poderosas faculdades.

É nesse tempo que hão de aparecer os verdadeiros intuitos literários; e não hoje em dia, quando o espírito, reclamado pelas preocupações da vida positiva, mal pode, em horas minguadas, babujar na literatura.

José de Alencar, 1872

Nenhum escritor teve em mais alto grau a alma brasileira.

Machado de Assis, 1937 
Parece perfeitamente correto ou legítimo afirmar que o Brasil pertence ao grupo das nações que não possuem um poema épico ou um romance nacional, ou então, melhor dir-se-ia, um livro nacional - visto que tal tipo de obra pode pertencer a diferentes gêneros literários - que as identifique. Já se pretendeu fazer de Os sertões a obra nacional por excelência, a Bíblia da nacionalidade brasileira (J. Nabuco), tal como ocorre com os Poemas homéricos para a Grécia, La Chanson de Roland para a França, a Obra dramatúrgica de Shakespeare para a Inglaterra, A divina comédia para a Itália, Dom Quixote para a Espanha, ou Os lusíadas para Portugal, ou em relação aos seus respectivos povos.

Tudo leva a crer, porém, que efetivamente não possuímos essa obra icônica.

Todavia, entre críticos e ensaístas da nossa historiografia literária há relativo consenso a respeito de ter sido José de Alencar o criador do nosso romance histórico, em especial nestes dois livros que são O Guarani (1857) e Iracema (1865); portanto, ter sido ele o autor do nosso romance fundacional. De fato, sua ampla descendência intelectual, confessadamente, em escritores como Machado de Assis, Euclydes da Cunha, Mário de Andrade, etc., tocados por seu estilo e sua obra, a ponto de ser reconhecido nele um como patriarca da literatura brasileira (Afrânio Coutinho). Mesmo estudiosos mais recentes chegam a afirmar, como Silviano Santiago, que Alencar não foi um espelho da sociedade, mas antes uma lanterna cuja luz, distribuída equitativamente por todo o Brasil, produziu um efeito unificador da nossa nacionalidade como representação e memória coletiva. Na verdade, seus dois romances mais célebres foram praticamente sacralizados por numerosas edições sucessivas até hoje e por sua adoção nos currículos escolares; a ópera Il Guarani, de Carlos Gomes (1870), suas muitas versões cinematográficas e, enfim, fato significativo, as inumeráveis crianças do Brasil que passaram a portar nomes de personagens e índios inventados por Alencar. ${ }^{1}$

1 José Martiniano de Alencar nasceu no dia $1^{\circ}$. de maio de $1829 \mathrm{em}$ Messejana, província do Ceará. Filho do futuro senador do Império, de igual nome, migra para a Corte (Rio de Janeiro), com o pai, entre 8 e 9 anos de idade; 
Nada obstante a riqueza e fecundidade dessa discussão, não é por esse ângulo, propriamente, que pretendo examinar a posição de José de Alencar (1829-1877) na cultura e nacionalidade brasileiras. Com efeito, a análise de O Guarani e Iracema como sendo o romance do Brasil já foi ampla e consistentemente realizada, dentre outros, pela especialista norte-americana Doris Sommer (1991), no capítulo sobre o Brasil em seu livro Foundational fictions: the national romances of Latin America, ou Renato Janine Ribeiro (2000) no estudo Iracema ou A fundação do Brasil inserido em seu livro A sociedade contra o social. Conforme sugere o título deste escrito, é meu intento enfatizar especialmente a deliberada missão intelectual, que Alencar se atribuiu, de realizar o projeto literário de construção da novel nação, ${ }^{2}$ saída de longo mergulho colonial, quando tudo estava por se fazer.

em seu opúsculo Como e porque sou romancista [de 1873, porém de publicação póstuma por Mário de Alencar. Rio de Janeiro: Tipografia de G. Leuzinger \& Filhos, 1893, 56 p.], ele assinala a impressão que lhe causou a exuberância da natureza brasileira no percurso por terra do Ceará à Bahia. Formado em direito, foi deputado geral em diversas legislaturas pelo Partido Conservador, chegando a ser ministro da Justiça entre 1868 e 1870. A despeito da sua atuação como jornalista, crítico teatral e dramaturgo, sua posição na literatura brasileira se deve especialmente à sua criação como romancista. Tendo por rumo seu projeto nacionalista, buscou elaborar a saga da nossa formação como Nação e Povo mediante as obras O guarani (1857), Iracema (1865), Ubirajara (1874), As minas de prata (1865-6) e A guerra dos Mascates (1871-3); bem como o registro da vida regional com os romances O gaúcho (1870), O tronco do ipê (1871), Til (1871) e O sertanejo (1875); e retratar a vida do seu tempo na Corte por meio quase sempre de perfis femininos, em seus romances urbanos Cinco minutos (1857), A viuvinha (1860) Lucíola (1862), Diva (1864), A pata da gazela (1870), Senhora (1875) e Encarnação (1877), etc. Morreu no Rio de Janeiro no dia 12 de dezembro de 1877.

2 Renato Janine explicita essa destinação ao afirmar: "Alencar, perguntado pela fundação da pátria, quer volver os olhos para o momento de seu nascimento, como prenhe de um futuro. Seja o nobre Peri do Guarani, seja a nobilíssima Iracema, sejam os fidalgos portugueses como D. Antônio ou Martim Soares Moreno, o que temos é uma origem destacada, em que avulta a vera nobilitas" (RIBEIRO, 2000, p. 60-61). Ao que ele ajunta em nota de rodapé à página 64, reportando-se ao Iracema: "Ora, se para Alencar a escrita sobre o Brasil se move pela necessidade de orientar, evitando a todo custo o extravio, em meio à estranheza que levaria o estrangeiro (ou o leitor) a se perder, então o papel do escritor tende a coincidir com o dos guias que aparecem nesse romance, a começar pela própria Iracema. Alencar pode assim estar no lugar de Iracema, nós, no de Martim, e nosso futuro, no de Moacir: o guia, que conhece as rotas, mas perece na empresa de ensiná-las; o aprendiz, estrangeiro na terra que deve 
Grosso modo, quase toda a vida e a obra de José de Alencar resultam de uma tensão interior agonística e exteriormente polêmica, que constitui o quadro da sua existência desde suas origens.

Machado de Assis, que acompanhou parte significativa da vida e da obra do seu amigo cearense, nutria profunda admiração por seu talento e intuía agudamente essa circunstância existencial com que foi elaborada a grandeza da sua criação ficcional, daí ter afirmado certa vez, de público, ao próprio Alencar, que "contra a conspiração do silêncio o ilustre escritor teria, um dia, a seu favor a conspiração da posteridade" (ASSIS, 1937, p. 333). Por sua vez, Capistrano de Abreu, que lhe havia feito restrições em 1875, cinco anos depois o defende dos ataques de Silvio Romero, para vaticinar: "A morte ainda não apagou, mas apagará em breve os sentimentos hostis; e então todos reconhecerão que José de Alencar é o primeiro vulto da literatura nacional" (ABREU, 1938, p. 178). E perdura até hoje a batalha para manter viva a perspectiva e a estética que sua obra produziu e inovou.

Examinei noutro trabalho sobre Alencar e a gênese de Iracema essa circunstância vital agonística que acompanhou seu esforço de criador cultural e que serve como um dos ângulos pertinentes à interpretação da sua obra. Eis por que aproveitarei aqui alguns pontos dessa reflexão. Tomo assim, para ilustrá-la, a posição do seu filho Mário de Alencar, em seu curto ensaio, José de Alencar, o escritor e o político, onde lhe traça de início, em síntese, um retrato cujos componentes serão desenvolvidos no restante do seu texto. Não diria perfeito tal retrato, porque traz as incongruências de todo esquematismo. Ajuda-nos, porém, na compreensão dessa personagem complexa que foi seu pai. Vejamos:

Em José de Alencar houve, reveladas na sua obra, duas pessoas distintas, que não se confundiram nem contrariaram, posto que contrárias uma à outra. Ele foi paralelamente um poeta de

ser sua, brasileiro alfabetizado das cidades do litoral, que ignora o verdadeiro Brasil, mas pode e deve conhecê-lo; a história futura do País, na síntese, feita de amor e de confronto, entre o mestre sacrificado e o aluno. Desse modo se forja o sentido de missão que uma escrita inaugural da Pátria possuiria" (Op.cit. p. 64, destaque do autor). 
idealizações extremas, e um homem prático e positivo: o primeiro dominado pela imaginação, pelo sentimento e pela fantasia, o segundo pela razão, pela realidade e pela prudência; no primeiro prevalecia o talento, no segundo a inteligência; a obra do primeiro criou-se espontaneamente, sem propósito; a do segundo foi o produto da vontade; unia-os um traço comum: a índole, a alma brasileira (ALENCAR, 1965, p. 89, destaques meus).

E acrescenta esta observação: "Definem-se na sua vida duas fases: a do poeta de ficção, de 1855 a 1868, e a do político, de 1868 a 1877" (Ibid.).

Parecem assim evidentes as virtudes desse retrato sintético, como a fraqueza da sua lógica dicotômica ou antidialética. De fato, a quem percorrer a vida e a obra do escritor revela-se de imediato que ele soube unir com algum equilíbrio, embora sob tensão, as duas faces de ficcionista exuberante e de político atuante, navegando socialmente nesses dois territórios com brilho próprio e sabedoria. Em Alencar, uma atividade não era incompatível com a outra.

Eis que nos inícios de novembro de 1860, o escritor retorna pela terceira vez ao Ceará, onde vai lutar por sua eleição à Câmara, aí demorando durante sua campanha. Na vinda, embarcado no Rio, ao passar por Recife, encontra-se com o sobrinho Tristão de Alencar Araripe Jr., então garoto de 11 anos que, duas décadas depois, publicará um dos melhores trabalhos que jamais foi escrito sobre a personalidade e a obra do seu tio. A 10 de janeiro de 1861, ao se realizarem as eleições secundárias para deputado geral, Alencar sai vitorioso. De volta à Corte, traz consigo, além do diploma de deputado, o esboço de Iracema - lenda do Ceará, cuja elaboração começara em plena luta política.

Em inúmeras passagens da sua obra e em especial em seus prefácios, posfácios, cartas, depoimentos, manifestos, etc., ${ }^{3}$

3 Veja-se, por exemplo, seu importante prefácio, intitulado "Bênção paterna" (1872), ao seu romance Sonhos d'ouro (in Ficção completa..., cit., vol. I, p. 491-498); ou ainda seu precioso depoimento Como e porque sou romancista (1873), publicação póstuma, por Mário de Alencar, Rio de Janeiro: Tipografia de G. Leuzinger \& Filhos, 1893, 56 p. (reproduzido no mesmo volume da sua ficção completa, p. 101-121). Estas constituem fontes indispensáveis para a compreensão do seu projeto ficcional romântico e nacionalista. 
Alencar deixa clara sua predileção pela literatura, ao mesmo tempo que o clima vivido desde a infância em família, sob o comando do pai, político militante, Ex-Presidente da sua Província (Ceará) e Senador, levaram-no à sedução pela política. O exemplo que dei acima basta para ilustrar a convergência dessas duas ações dominantes em sua conduta e ao longo da sua existência.

Mas quero examinar ainda outro ponto discutível da citação de Mário de Alencar. Refiro-me à outra cisão artificial ali afirmada: não aquela relativa às supostas duas pessoas distintas em Alencar, mas às supostas vertentes diversas em sua obra, tanto por seu conteúdo quanto por seus fins. A saber, uma vez aceita a existência de duas pessoas distintas em Alencar, segue-se logicamente a dicotomia da sua produção intelectual. O artifício dessa visão se acentua quando o autor insiste em dizer que a poética ficcional alencariana fora dominada pela imaginação, pelo sentimento e pela fantasia, ao passo que sua obra política o era pela razão, a realidade e a prudência; que naquela prevalecia o talento, nesta a inteligência; que a primeira fora criada espontaneamente e sem propósito [sic], já a segunda nascera da vontade. Todavia, como a retificar o equívoco desse corte epistêmico absoluto, ele afirma a existência de um traço comum unindo as duas vertentes: a índole brasileira, nossa alma coletiva.

Mário conhecera decerto seu pai e sua obra. Como, pois, lhe foi possível admitir tal cisão em sua personalidade e em sua produção? Para não falar da artificial disjunção entre as funções criativas do espírito: de um lado, a imaginação, o talento e o sentimento, e, de outro, a razão, a inteligência e a vontade. Ora, a pulsão criativa do ser humano em qualquer campo do conhecimento e da cultura é sempre uma atividade compósita que engaja todas suas dimensões e possui no imaginário sua matriz criadora fundamental.

Mas avanço um pouco mais na visão de Mário sobre seu pai, quando sustenta ser sua produção política nascida da vontade de homem prático e positivo, isto é, de escolha racionalmente instrumental e orientada; ao passo que sua criação ficcional surgia espontaneamente e sem propósito [sic]. Eis, sem dúvida, a porção mais frágil do seu argumento. Ela destrói ou apaga o imenso esforço que fez seu pai no sentido de nos livrar do legado colonial 
reinol, construindo simbolicamente a jovem nação por meio da sua poética ficcional. E para evitar mal-entendidos, assinalo que uso o termo "poética" em sua acepção aristotélica original.

Alencar acalenta um propósito deliberado em sua missão de escritor, ficcionista, poeta, dramaturgo, jornalista e político, rumo à construção da nação, da sua linguagem e da sua simbólica, garantes da consciência coletiva de um povo livre e diferenciado. Sua forte intuição política e estética fazia dele a consciência mais lúcida para perceber que uma nação livre se constrói, sobretudo, por sua língua e sua literatura mediante amplos processos discursivos e criativos. Sua refinada percepção da nossa realidade em seu tempo fazia dele polemista destemido e cônscio do poder da palavra, instrumento especificador por excelência da humana condição e da nossa singularidade cultural: dimensões a interagir numa totalidade que se refaz incessantemente.

Um exemplo expressivo desse desiderato consciente está no referido prefácio do seu romance Sonhos d'ouro (1872). Embora, nas páginas iniciais, exprima com um grão de ironia seu desagrado pela campanha sistemática contra suas obras e que ele próprio atribua certa insignificância a seus escritos, há um momento no qual, após contestar as principais críticas, assume claramente a posição de quem vai dar um balanço em sua obra, dirigindo-se ao livro que prefacia, como se fosse um observador estranho àquele objeto, a antecipar os percalços que este iria enfrentar. Acentua então a convergência das supostas vertentes da sua produção:

Que fortuna para teu autor, livrinho, se lhe tirassem essa querida ilusão literária, como já lhe arrancaram o outro puro entusiasmo da política: essas duas cordas da pátria, essa gêmea aspiração do belo e do grande, que afagava-lhe os sonhos da mocidade e tocava-os de luz esplêndida (ALENCAR, 1872, p. 495, destaques meus).

E, depois de descrever com sarcasmo as condições de criação literária no país e de lançar irônicas metáforas contra os processos de consagração de mediocridades, prossegue na sua contestação dos adversários: 
Quanto ao segundo defeito que te hão de notar, de ires um tanto desbotado do matiz brasileiro, sem aquele picante sabor da terra: provém isso de uma completa ilusão dos críticos a respeito da literatura nacional.

Eis uma grande questão, que por aí anda mui intrincada e de todo ponto desnorteada, apesar de tão simples e fácil que é. Lá uns gênios de Portugal, compadecendo-se de nossa penúria, tomaram a si decidir o pleito, e decretaram que não temos, nem podemos ter literatura brasileira.

A grande inteligência de Alexandre Herculano nos profetizava uma nacionalidade original, transfusão de duas naturezas, a lusa e a americana, o sangue e a luz. Mas os ditadores não o consentem; que se há de fazer? Resignemo-nos. Este grande império, a quem a Providência rasga infindos horizontes, é uma nação oca; não tem poesia nativa, nem perfume seu...

Os oráculos de cá, esses querem que tenhamos uma literatura nossa; mas é aquela que existia em Portugal antes da descoberta do Brasil. [...].

Bem vês, livrinho, que uma questão desta monta não é para teu modesto topete, e sim para algum prólogo campanudo, obra de bom punho.

$[\ldots]$.

Aos que tomam ao sério estas futilidades de patriotismo, e professam a nacionalidade como uma religião, a esses hás de murmurar baixinho ao ouvido, que te não escutem praguentos, estas reflexões:

A literatura nacional que outra cousa é senão a alma da pátria, que transmigrou para este solo virgem com uma raça ilustre, aqui impregnou-se da seiva americana desta terra que lhe serviu de regaço; e cada dia se enriquece ao contacto de outros povos e ao influxo da civilização? (Op. cit., p. 495-496).

Isso posto, Alencar procede a uma sucinta análise dessa construção de uma literatura brasileira, propondo sua periodização em três etapas ${ }^{4}$ e ilustrando-a com sua própria obra, num balanço que

4 Evidentemente, suas concepções, embora representem alto grau de consciência possível da sua circunstância existencial, sofrem os limites dos horizontes de conhecimento antropológico e histórico do seu tempo: como, 
mostra sua inserção num projeto deliberado. Ele acrescenta, ao final, agudo questionamento sobre as feições da sociedade que se vai configurando por esse esforço criativo e retira daí conclusões de uma lucidez e atualidade espantosas. Vale a pena transcrever os trechos principais desta bela página repleta de finura e argúcia:

O período orgânico dessa literatura conta já três fases.

A primitiva, que se pode chamar aborígine, são as lendas e mitos da terra selvagem e conquistada; são as tradições que embalaram a infância do povo, e ele escutava como o filho que a mãe acalenta no berço com as canções da pátria, que abandonou.

Iracema pertence a essa literatura primitiva, cheia de santidade e enlevo, para aqueles que veneram na terra da pátria a mãe fecunda - alma mater, e não enxergam nela apenas o chão onde pisam.

O segundo período é histórico: representa o consórcio do povo invasor com a terra americana, que dele recebia a cultura, e lhe retribuía nos eflúvios de sua natureza virgem e nas reverberações de um solo esplêndido.

Ao aconchego desta pujante criação, a têmpera se apura, toma alas a fantasia, a linguagem se impregna de módulos mais suaves; formam-se novos costumes, e uma existência nova, pautada por diverso clima, vai surgindo.

É a gestação lenta do povo americano, que devia sair da estirpe lusa, para continuar no novo mundo as gloriosas tradições de seu progenitor. Esse período colonial terminou com a Independência.

A ele pertencem O Guarani e As Minas de Prata. Há aí muita e boa messe a colher para o nosso romance histórico; mas não exótico e raquítico como se propôs a ensiná-lo, a nós beócios, um escritor português.

A terceira fase, a infância de nossa literatura, começada com a independência política, ainda não terminou; espera escritores que lhe dêem os últimos traços e formem o verdadeiro gosto

por exemplo, quando opõe cultura e natureza para descrever o processo de assimilação entre lusitanos e indígenas, respectivamente. Assim, apesar de não deslizar para a tradicional oposição entre civilização e barbárie, é evidente no caso a simplificação do seu esquematismo. Outro fato saliente a sublinhar em seu quadro interpretativo e no da sua época reside no estranho silêncio sobre a dominante presença negra. 
nacional, fazendo calar as pretensões hoje tão acesas, de nos recolonizarem pela alma e pelo coração, já que não o podem pelo braço.

Neste período a poesia brasileira, embora balbuciante ainda, ressoa, não já somente nos rumores da brisa e nos ecos da floresta, senão também nas singelas cantigas do povo e nos íntimos serões da família.

Onde não se propaga com rapidez a luz da civilização, que de repente cambia a cor local, encontra-se ainda em sua pureza original, sem mescla, esse viver singelo de nossos pais, tradições, costumes e linguagem, com um sainete todo brasileiro. Há, não somente no país, como nas grandes cidades, até mesmo na Corte, desses recantos que guardam intacto, ou quase, o passado.

O Tronco do Ipê, O Til e O Gaúcho, vieram dali; embora, no primeiro sobretudo, se note já, devido à proximidade da Corte e à data mais recente, a influência da nova cidade, que de dia em dia se modifica e se repassa do espírito forasteiro.

Nos grandes focos, especialmente na Corte, a sociedade tem a fisionomia indecisa, vaga e múltipla, tão natural à idade da adolescência. É o efeito da transição que se opera; e também do amálgama de elementos diversos.

A importação contínua de idéias e costumes estranhos, que dia por dia nos trazem todos os povos do mundo, devem por força de comover uma sociedade nascente, naturalmente inclinada a receber o influxo de mais adiantada civilização.

Os povos têm, na virilidade, ${ }^{5}$ um eu próprio, que resiste ao prurido da imitação; por isso na Europa, sem embargo da influência que sucessivamente exerceram algumas nações, destacam-se ali os caracteres bem acentuados de cada raça e de cada família.

Não assim os povos não feitos; estes tendem como a criança ao arremedo; copiam tudo, aceitam o bom e o mau, o belo e o ridículo, para formarem o amálgama indigesto, limo de que deve sair mais tarde uma individualidade robusta.

5 Alencar emprega com frequência esse termo virilidade em sua acepção de idade adulta (idade viril), a da capacidade de procriar; em especial nesse texto em que utiliza uma metáfora antropomórfica das idades do ser humano para caracterizar períodos da formação sociocultural da nossa nação. 
Palheta, onde o pintor deita laivos de cores diferentes, que juntas e mescladas entre si, dão uma nova tinta de tons mais delicados, tal é a nossa sociedade atualmente. Notam-se aí, através do gênio brasileiro, umas vezes embebendo-se dele, outras invadindo-o, traços de várias nacionalidades adventícias; é a inglesa, a italiana, a espanhola, a americana, porém especialmente a portuguesa e francesa, que todas flutuam, e a pouco e pouco vão diluindo-se para infundir-se n'alma da pátria adotiva, e formar a nova e grande nacionalidade brasileira.

Desta luta entre o espírito conterrâneo e a invasão estrangeira, são reflexos Lucíola, Diva, A Pata da Gazela, e tu, livrinho, que aí vais correr mundo com o rótulo de Sonhos D'Ouro (Ibid, destaques do autor).

É neste ponto que Alencar retoma seus questionamentos contra as posições adversárias dos seus críticos, e dessas reflexões extrai com argúcia suas conclusões esclarecedoras:

Tachar estes livros de confeição estrangeira é, relevem os críticos, não conhecer a fisionomia da sociedade fluminense, que aí está a faceirar-se pelas salas e ruas com atavios parisienses, falando a algemia universal, que é a língua do progresso, jargão erriçado de termos franceses, ingleses, italianos e agora também alemães.

Como se há de tirar a fotografia desta sociedade, sem lhe copiar as feições? Querem os tais arqueólogos literários que se deite sobre a realidade uma crosta de classismo, como se faz com os monumentos e os quadros para dar-lhes o tom e o merecimento do antigo?

\section{$[\ldots]$.}

Em vez de andarem assim a tasquinhar com dente de traça nos folhetinistas do romance, da comédia, ou do jornal, por causa dos neologismos de palavra e de frase, que vão introduzindo os novos costumes, deviam os críticos darem-se a outro mister mais útil, e era o de joeirar o trigo do joio, censurando o mau, como seja o arremedo grosseiro, mas aplaudindo a aclimatação da flor mimosa, embora planta exótica, trazida de remota plaga.

Sobretudo compreendam os críticos a missão dos poetas, escritores e artistas, nesse período especial e ambíguo da formação de uma nacionalidade. São estes os operários incumbidos de polir o talhe e as feições da individualidade que se vai esboçando no viver do povo. Palavra que inventa a multidão, inovação que adota o uso, caprichos que surgem no espírito do idiota inspirado: tudo isto lança o poeta no seu cadinho, para 
escoimá-lo das fezes que porventura lhe ficaram do chão onde esteve, e apurar o ouro fino (destaques meus).

E de quanta valia não é o modesto serviço de desbastar o idioma novo das impurezas que lhe ficaram da refusão do idioma velho com outras línguas? Ele prepara a matéria, bronze ou mármore, para os grandes escultores da palavra que erigem os monumentos literários da pátria (Idem).

$[\ldots]$.

Assim foi por toda parte; assim há de ser no Brasil. Vamos pois, nós, os obreiros da fancaria, desbravando o campo, embora apupados pelos literatos de rabicho. Tempo virá em que surjam os grandes escritores para imprimir em nossa poesia o cunho do gênio brasileiro, e arrancando-lhe os andrajos coloniais de que andam por aí a vestir a bela estátua americana, a mostrem ao mundo, em sua majestosa nudez: naked majesty. ${ }^{6}$

Toda a produção literária de Alencar está assim inelutavelmente inserida no horizonte estético do romantismo. Quadro, portanto, no interior do qual se envolveu com a gama de questionamentos das duas décadas em que buscou intensamente realizar a construção da nacionalidade por meio da sua poética ficcional. Parece legítimo afirmar que, após nossa independência política, os dois pontos de inflexão mais relevantes dessa busca e afirmação da singularidade do nosso país como Povo e Nação foram o romantismo e o movimento modernista, tomado este, porém, em seu sentido mais amplo, incluindo autores que antecedem a Semana de 1922 e seus desdobramentos ulteriores. Se o romantismo foi pensado inicialmente em Paris (1836) por Domingos de Magalhães e amigos, com muitos suspiros poéticos e saudades, foi, porém, com Alencar que ele se adensou na sua forma de desenho cultural da brasilidade, visto ter sido este quem alargou, com seu obstinado projeto literário, o horizonte da consciência possível da sua época.

6 "Bênção paterna", prefácio de Sonhos d'Ouro, in Ficção completa, p. 494-497. 
Não gostaria de concluir essas notas sem uma reflexão paralela sobre as relações entre escritor e público, espécie no caso de consideração ainda que sumária sobre algo que se poderia denominar uma sociologia da inteligência brasileira no período. Sempre que me debruço sobre essa fase dos primórdios da formação da nossa nacionalidade pós-Independência, assalta-me o espanto que me causam os escritores da época e em especial Alencar e Machado de Assis que - em face de um público no qual predominavam o analfabetismo geral e a cultura da oralidade, e de uma centena se muito de leitores cultos e capazes de apreender a significação da obra que eles produziam - se mostrassem, no entanto, na obstinação e teimosia do exercício do seu ofício: de onde nascia essa pulsão criativa que se confrontava com tanta hostilidade, incompreensão ou indiferença?

Que me seja permitido arrimar-me em passagens de belo e lúcido ensaio de Augusto Meyer, intitulado Alencar e a tenuidade brasileira, incluído no volume II da Ficção completa e outros escritos do escritor (ALENCAR, 1965, p. 11-24).

Ele inicia suas considerações por lembrar que, se o leitor de novelas de cavalaria, ou seja, o "Dom Quixote" dos bons tempos, só pedia a um autor que lhe desse a ilusão do imprevisto, do deleitoso e do sublime, como poderia ele aceitar a questão do matemático Roberval - "Qu'est-ce que cela prouve?" - ao cair o pano na última cena de Polyeucte. Evoca isso para qualificar de "nosso triste robervalismo" a reação de Monteiro Lobato diante das façanhas do índio Peri, em Idéias de Jeca Tatu, esterilizadora mania realista; e comenta: "Não saber adaptar-se à perspectiva ideal que uma obra exige para ser bem contemplada, parece-me um dos pecados mortais da crítica". Depois de desdobrar tais considerações, conclui este tópico, afirmando:

Eu por mim confesso humildemente que não vejo indígenas na obra de Alencar, nem personagens históricos, nem romances históricos; vejo uma poderosa imaginação que transfigura tudo, a tudo atribui um sentido fabuloso e não sabe criar senão dentro de um clima de intemperança fantasista. Poeta do romance, romanceava tudo. Se teve a intenção de criar o nosso romance histórico, ficou só na intenção, e de qualquer modo não lograria fazê-lo, pois era demasiado genial para poder adaptar seu fogoso temperamento a um gênero tão medíocre, que pede paciência aturada na imitação da crônica histórica [...] (Ibid.). 
Mas passemos às reflexões relativas ao ponto que me inquieta e cujo questionamento ora formulei: a obstinação criativa do projeto nacional de Alencar ante a tenuidade brasileira de então.

Ora, os fatos, assim como os textos, são mudos: só falam se interrogados. Ao que Augusto Meyer ajunta: tudo é mudo nas formas a que não sabemos insuflar um verbo. E cita a observação de Marc Bloch, em seu Métier d'historien, segundo a qual a abundância de sílex sempre houve nas aluviões, mas a pré-história só começa com Boucher de Perthes (1788-1868), que soube interrogar, dialogar e responder pelas pedras; e o historiador acrescenta: "Toute recherche historique suppose, dès ses premiers pas, que l'enquête ait déjà une direction. Au commencement est l'esprit. Jamais, dans aucune Science, l'observation passive n'a rien donné de fécond. A supposer, d'aillerus, qu'elle soit possible".

Na criação literária, ainda parece mais evidente essa força do espírito, no encadeamento de influências a provocar revelações na dependência de um catalisador oportuno; assim, nosso indianismo só teve alento sob a influência do romantismo francês (Bernardin de Saint-Pierre e Chateaubriand), e enquanto isso não foi percebido, o romance brasileiro não se esboçou. E isso se deu com os dois poderosos fatores da poíesis ficcional românica, a "distância no espaço" - o exotismo - e a "distância no tempo" - primitivismo, o medievalismo, as idades recuadas [...] - mas o primeiro reagiu paradoxalmente, no nosso caso, atribuindo sabor de novidade estranha e exótica ao que era costumeiro e familiar. Ao que A. Meyer acrescenta: mas o paradoxo era uma consequência inevitável das condições de desterro cultural em que vivíamos; no fundo, como ainda hoje ocorre, éramos estrangeiros em nossa terra, sentíamos nossas coisas como exilados da fantasia - o índio, a selva, a paisagem grandiosa, as feracidades americanas tinham sabor inconsciente de exotismo; estávamos e ainda estamos ausentes; e só nos veio a revelação da presença mui tardiamente, em plena reação contra o Romantismo, a rigor, a partir do Modernismo.

O autor enfatiza essa condição ao afirmar que é o caso de Alencar: estamos em face de verdadeiro drama, que ultrapassa a criação literária, comprovação desse vazio da tenuidade brasileira manifesta em nosso sentimento de inferioridade diante do 
amplo legado cultural do Ocidente, em nossa pobre literatura de remediados, de bacharéis de Coimbra e saudosistas de Paris, todos exilados em sua terra. E Alencar, mais que um Gonçalves Dias e outros, devia enfrentar uma criação ex nihilo; como "será mais tarde o problema de Mário de Andrade na rapsódia do herói sem nenhum caráter, com a diferença, todavia, de um travo consciente de autocrítica".

Foi provavelmente Capistrano de Abreu quem por primeiro ergueu o véu dessa nossa contradição fundamental e de nosso sentimento de inferioridade assinalado, quando ainda jovem, migrado de sua província natal para a Corte em 1875, enfrentando o prestígio intelectual de Sílvio Romero, numa série de dois longos artigos intitulados "O caráter nacional e as origens do povo brasileiro", publicados em $O$ Globo, Rio de Janeiro, 21 de janeiro e 9 de março de 1876 (ABREU, 1976, p. 3-24).

Mas foi Sérgio Buarque de Holanda quem, em Raízes do Brasil, sublinhou e reforçou a consciência plena dessa experiência agonística da tenuidade brasileira, dessa indecisão contraditória, "como ideia-força criadora", e vivida em profundidade pela geração modernista, ao afirmar: "Trazendo de países distantes nossas formas de convívio, nossas instituições, nossas idéias, e timbrando em manter tudo isso em ambiente desfavorável e hostil, somos ainda hoje uns desterrados em nossa terra" (HOLANDA, 1991, p. 3).

Nessa mesma ordem de considerações, o autor em cujo texto me arrimo assinala ainda que Tristão de Athayde, num dos seus estudos das quatro primeiras séries, acentuava em nosso romancista a vigorosa tensão da vontade, seu lado consciente e construtivo em detrimento do seu impulso vocacional:

Esse desejo de afirmar-se foi sempre típico em Alencar. Sua obra não foi propriamente uma obra de vocação [...]. Escrevia por querer, escolhendo bem os seus motivos e distribuindo a sua atividade de romancista de modo a abranger de fato todas as faces da nacionalidade, cuja literatura era preciso criar (ESTUDOS, vol. 4, destaques meus).

E a essa observação consistente Augusto Meyer ajunta esta outra de Antonio Candido, em seu estudo O escritor e o público em que, após percorrer essa relação ao longo de nossa produção literária, afirma com lucidez: 
[...] escritor e público definiram-se aqui em torno de duas características decisivas para a configuração geral da literatura: retórica e nativismo, fundidos no movimento romântico depois de um desenvolvimento anterior paralelo. [...] Desse modo, formou-se, dispensando o intermédio da página impressa, um público de auditores [...] A grande maioria dos nossos escritores, em prosa e verso, fala de pena em punho e prefigura um leitor que ouve o som da sua voz brotar a cada passo por entre as linhas (CANDIDO, 1967, p. 93-94, destaque meu).

Portanto, sem pretender um fechamento precoce do argumento, eis um sumário das minhas reflexões sobre essa temática ou das minhas hipóteses interpretativas.

\section{REFERÊNCIAS}

ABREU, J. C. H. Ensaios e estudos (crítica e história), $4^{\mathrm{a}}$ série. Edição preparada e prefaciada por José Honório Rodrigues. Rio de Janeiro: Civilização Brasileira; Brasília: INL, 1976. caps. 7, 8, 9 e 10, p. 42-58.

. História pátria: a literatura brasileira e a crítica moderna ensaio de generalização, por Sylvio Romero. In: Ensaios e estudos (crítica e história), 3a série. Rio de Janeiro: Edição da Sociedade Capistrano de Abreu - Livr. Briguiet, 1938. p. 151-178.

ACADEMIA CEARENSE DE LETRAS. Alencar 100 anos depois. Homenagem da ACL ao escritor, no centenário de sua morte. Fortaleza: Edição da ACL, 1977. (Col. Antonio Sales, n. 7, 22 textos de VV.AA.).

ALENCAR, H. José de Alencar e a ficção romântica. In: COUTINHO, Afrânio (Dir.). A literatura no Brasil. Rio de Janeiro: J. Olympio / EDUFF, 1986. v. III, p. 231-321.

ALENCAR, J. Ao correr da pena. Edição preparada por João Roberto Faria. São Paulo: Martins Fontes, 2004.

Ficção completa e outros escritos. Organização de Wanderley Guilherme dos Santos. Edição fac-similar. Rio de Janeiro: Editora da UFRJ, 1991.

Bênção paterna (prefácio). In: Sonhos d'ouro. Rio de Janeiro: [s.n.], 1872.

ALENCAR, M. In: ALENCAR, J. Ficção completa e outros 
escritos. Rio de Janeiro: Nova Aguilar, 1965. p. 89.

ARARIPE JUNIOR. Sob o signo de Alencar. In: Teoria, crítica e história literária. Seleção e apresentação de Alfredo Bosi. São Paulo: LTC / EdUSP, 1978. p. 1-111.

ASSIS, M. Crítica literária. Rio de Janeiro: W. M. Jackson, 1937.

BARBOSA, F. A. Nacionalismo e literatura e José de Alencar, cronista do primeiro encilhamento. In: Achados do vento. Rio de Janeiro: MEC - INL, 1958. p. 13-52, 119-128. (Biblioteca de Divulgação Cultural, série A - XV).

BOSI, A. Um mito sacrificial: o indianismo de Alencar. In:

Dialética da colonização. São Paulo: Cia. das Letras, 1992. p. 176-193.

CANDIDO, A. O escritor e o público. In: Literatura e sociedade - estudos de teoria e história literária. São Paulo: CEN, 1967. p. 84-102.

. Os três alencares. In:

Formação da literatura brasileira. São Paulo: Martins, 1964. v. 2, p. 218-232.

CASTELLO, J. A. Literatura brasileira - origens e unidade (15001960). São Paulo: EdUSP, 1999.

FARIA, J. R. O nacionalismo no romance e no teatro de José de Alencar. In: O teatro na estante - ensaios sobre dramaturgia brasileira e estrangeira. São Paulo: Ateliê, 1998. p. 47-54.

HOLANDA, A. B. (Org.). O romance brasileiro. Rio de Janeiro: Edições O Cruzeiro, 1952. p. 85-95.

HOLANDA, S. B. Raízes do Brasil. 22. ed. Rio de Janeiro: J. Olympio, 1991. (Coleção Documentos do Brasil).

LEITE, D. M. Romantismo: a independência e a formação de uma imagem positiva do Brasil e dos brasileiros. In:

O caráter

nacional brasileiro - história de uma ideologia. 2. ed. São Paulo: Pioneira, 1969. p. 163-177 
LIMA, R. A. R. Senhora. In: Crítica e literatura. Prefácio de Capistrano de Abreu, introdução e notas de Djacir Menezes. 3. ed. Fortaleza: Imprensa Universitária do Ceará, 1968. p. 201-225.

LINHARES, T. Nacionalismo estético (J. de Alencar). In:

História crítica do romance brasileiro 1728-1981. Belo Horizonte: Itatiaia / EdUSP, 1987. t. I, cap. II, p. 81-103.

MENEZES, E. D. B. Alencar e Poe: leitores de si mesmos. Revista de Letras (UFC), Fortaleza, v. 1, n. 29, p. 31-41, jan./jun. 2009.

. O gaúcho - sua posição na obra de José de Alencar: como lê-lo hoje?. In: ALENCAR, José de. O gaúcho. Edição especial comentada. Fortaleza: Grandene / Secretaria de Cultura do Estado, 2006. p. 14-25.

MENEZES, R. Dicionário literário brasileiro. Prefácio de Antonio Candido. Apresentação de José Aderaldo Castello. 2. ed., rev. e aum. Rio de Janeiro: LTC, 1978.

Cartas e documentos de José de Alencar. 2. ed. S. Paulo: Hucitec / INL, 1977. 1965.

. José de Alencar, literato e político. São Paulo: Martins,

MONTENEGRO, O. José de Alencar. In:

O romance brasileiro. Prefácio de Gilberto Freyre. Rio de Janeiro: J. Olympio, 1953. p. 47-59. (Coleção Documentos Brasileiros - 10).

MONTENEGRO, P. P. Prosa e narrativa em José de Alencar. In: . CASTRO, Silvio (Dir.). História da literatura brasileira.

Lisboa: Publicações Alfa, 1999. vol. II, cap. 22, p. 127-152.

RIBEIRO, R. J. Iracema ou a fundação do Brasil. In: A sociedade contra o social - o alto custo da vida pública no Brasil. Ensaios. São Paulo: Cia. das Letras, 2000. p. 45-64.

SCHWARZ, R. A importação do romance e suas contradições em Alencar. In: Ao vencedor as batatas. São Paulo: Duas Cidades, 1977. p. 29-60. 
SODRÉ, N. W. José de Alencar, a ficção numa sociedade escravocrata. In: A ideologia do colonialismo - seus reflexos no pensamento brasileiro. Rio de Janeiro: ISEB, 1961. p. 35-57.

SOMMER, D. Foundational fiction: the national romances of Latin America. Berkeley: University of California Press, 1991. 